\title{
Tank-mix Options for Control of Tropical Soda Apple and Dogfennel ${ }^{1}$
}

\section{B.A. Sellers and J.A. Ferrell ${ }^{2}$}

Tropical soda apple (TSA) continues to be a problem in Florida pastures, but other weeds are often present in significant numbers. Dogfennel is the most widely encountered weed in Florida pastures and it is commonly found growing along with TSA (Figure 1). Although Milestone is highly effective on TSA, it provides little or no dogfennel control. Likewise, Forefront (a mixture of 2,4-D and Milestone) is more effective than Milestone, but still fails to control large dogfennel.plants To illustrate, UF-IFAS research has shown that Forefront applied at 2 pints/acre was excellent on TSA, but highly inconsistent (30 to $95 \%$ control) when dogfennel was 30 inches or greater in height. Increasing the rate to 2.6 pints/acre improved the consistency of control for 30 inch-tall dogfennel, but failed to control plants that were 40 inches tall or greater. Since TSA and dogfennel of all sizes are common throughout Florida, Forefront + another herbicide will be required to effectively control both species.

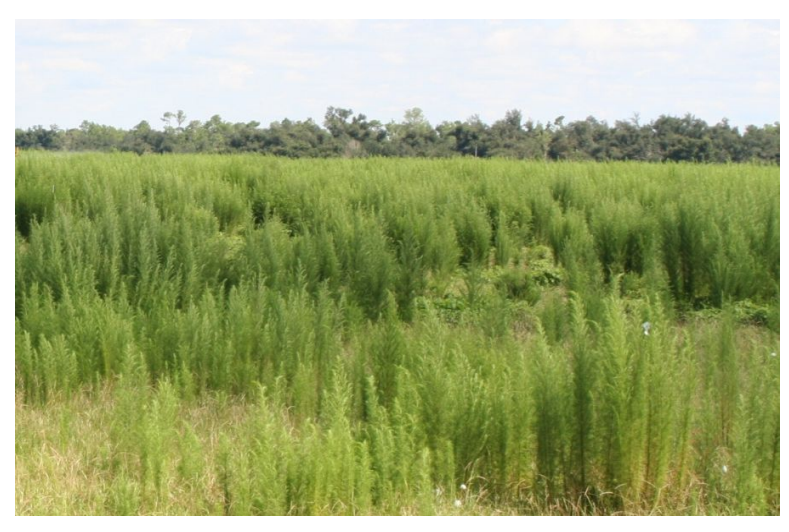

Figure 1. A bahiagrass pasture infested with dogfennel and TSA. Credits: Photograph by Brent Sellers.

To determine what herbicides could be tank-mixed with Forefront to provide adequate control of both dogfennel and TSA, many combinations were tested. The ultimate goal was to maximize weed control without adding more than $\$ 6 /$ acre to 2 pints/acre of Forefront; the total cost of the final tank-mix should not exceed \$20/A. The most promising combinations were $10 \mathrm{fl} \mathrm{oz} / \mathrm{A}$ of Vista, 1 pint/acre of Pasturegard, 2 pints/acre of WeedMaster, or 3 pints/acre of 2,4-D amine. Each of the herbicides, when mixed with 2 pints/acre of Forefront, provided at least $88 \%$ control

1. This document is SS AGR 300, one of a series of the Agronomy Department, Florida Cooperative Extension Service, Institute of Food and Agricultural Sciences, University of Florida. Original publication date January 2008. Visit the EDIS Web Site at http://edis.ifas.ufl.edu.

2. B.A. Sellers, assistant professor, Range Cattle Research and Education Center--Ona, FL; J. A. Ferrell, assistant professor, Agronomy Department; Florida Cooperative Extension Service, Institute of Food and Agricultural Sciences, University of Florida, Gainesville, FL 32611.

The use of trade names in this publication is solely for the purpose of providing specific information. UF/IFAS does not guarantee or warranty the products named, and references to them in this publication does not signify our approval to the exclusion of other products of suitable composition. All chemicals should be used in accordance with directions on the manufacturer's label. 
of 40 inch dogfennel 60 days after treatment

(Figure 2). TSA control with these

tank-mixtures was approximately $90 \%$ at 60

days after treatment.

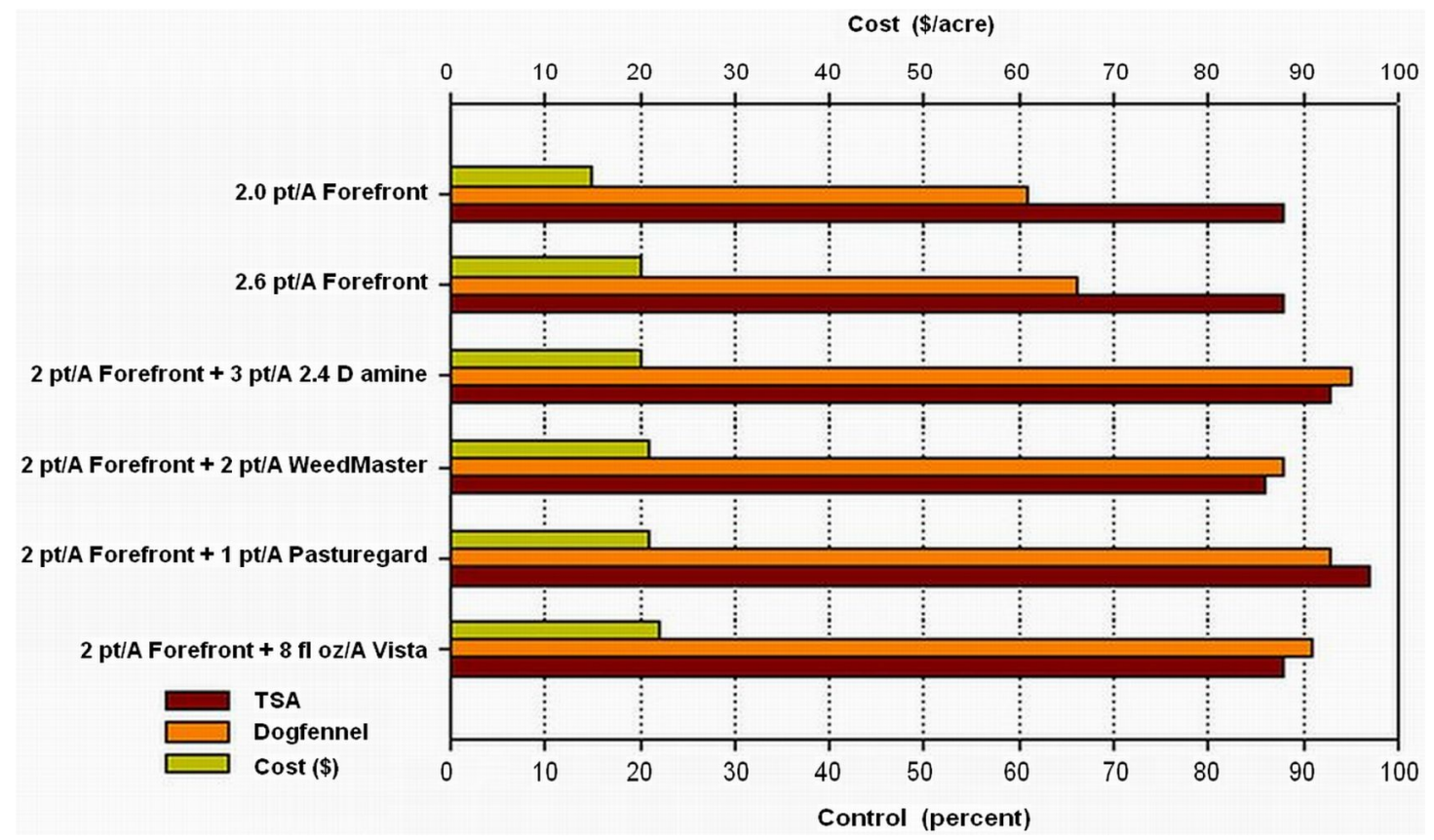

Figure 2. Response of tropical soda apple and dogfennel with 2.0 and 2.6 pt/acre of Forefront alone and 2 pints/acre of Forefront plus 2,4-D amine, WeedMaster, Pasturegard, or Vista. Herbicide prices shown in the graph are approximate and do not include application costs.

In Figure 2, the addition of \$4-6/acre increases dogfennel control from $60 \%$ with Forefront to at least $88 \%$ with Forefront and one of the four tank-mix partners. Therefore, as you scout your pastures for TSA, be sure to also look for other weeds as well. If you have pastures with both dogfennel and TSA, consider one of these four tank-mix options to get the most for your money.

The tank-mix treatments in Figure 2 were applied on a large scale to demonstrate the success of these tank-mix treatments. All treatments performed similarly (Figure 3), but dogfennel at the time of application was at least 6 feet tall. Therefore, these tank-mix combinations can be utilized for both dogfennel and TSA control at any growth stage.

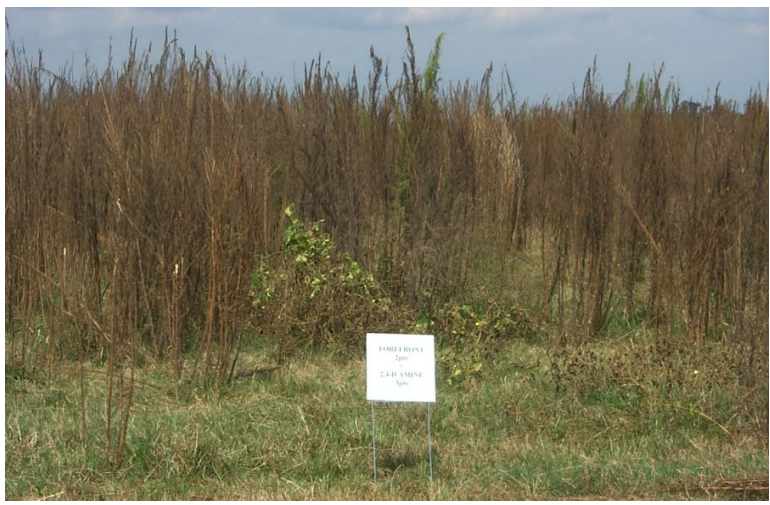

Figure 3. Dogfennel control with 2.0 pints/acre Forefront plus 3 pints/acre 2,4-D amine 60 days after a large scale pasture application. 